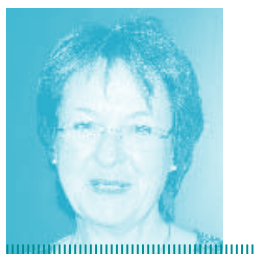

Sidsel Riisberg Paulsen, kreftsykepleier, USHT Vestfold

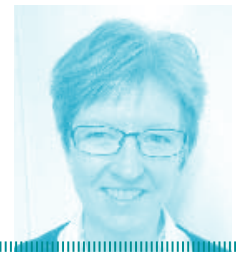

Inger Lise Elvestuen palliativ sykepleier, Lindrende enhet, Nygård bo- og behandlingssenter

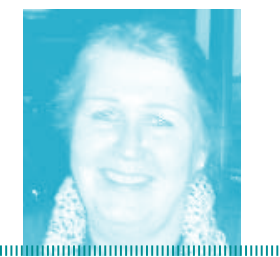

Trine Merete EdlerWoll, sykepleier, Lindrende enhet, Byskogen bo- og aktivitetssenter, Larvik



Astri M. Andersson, kreftsykepleier, hjemmetjenesten, Stokke kommune
Jorunn Abrahamsen,

kreftsykepleier, Lindrende enhet, Braarudåsen senter

\title{
Kvalitetssikrer omsorg til døende
}

\author{
Liverpool Care Pathway (LPC) er en tiltaksplan og dokumentasjonsmetode \\ som fører til bedre omsorg og behandling i livets siste dager.
}

$\mathbf{G}$ od lindrende behandling og pleie i livets sluttfase har stor betydning for pasient og pårørende: «Hvordan mennesker dør, forblir som viktige minner hos dem som lever videre. Både av hensyn til dem og til pasienten, er det vår oppgave å kjenne til hva som forårsaker smerte og plager, og hvordan vi kan behandle disse plagene effektivt. Det som skjer de siste timene før et menneske dør, kan lege mange tidligere sår, eller forbli som uutholdelige erindringer som forhindrer veien gjennom sorg»(1, s. 1).

Optimal behandling, pleie og omsorg for døende og deres pårørende fordrer kunnskap, kompetanse, empati og engasjement hos alle involverte parter. Bruk av standardiserte tiltaksplaner i tillegg kan bidra til kvalitetssikring

\section{Hovedbudskap}

Artikkelen omhandler et implementeringsprosjekt Vestfold fylke. Målet med prosjektet var å implementere Liverpool Care Pathway, LCP, i fylkets 14 kommuner samt ved én seksjon på sykehuset i Vestfold HF. Hensikten var å kvalitetssikre omsorgen til døende og deres pårørende, samt bedre dokumentasjonen av denne. I artikkelen beskriver vi bakgrunn for, organisering, og implementering av, resultater fra og erfaringer med prosjektet, som pågikk i perioden 2011-2013. Prosjektet var delvis finansiert ved tilskuddsmidler fra Helsedirektoratet.

\section{Nøkkelord}

Les mer og finn litteraturhenvisninger på våre nettsider. > Død > Palliasjon , Kvalitet
Liverpool Care Pathway, LCP, er en internasjonal anerkjent tiltaksplan for å kvalitetssikre omsorgen til døende og deres pårørende. Planen gir evidensbasert veiledning til de ulike aspektene ved omsorg for døende (2). LCP tiltaksplan fungerer som retningslinjer for pleie og omsorg, og som dokumentasjonsverktøy (3).

LCP kan anvendes til døende pasienter i sykehus, ved palliative enheter, sykehjem og i hjemmet, og er uavhengig av pasientens diagnose. Tiltaksplanen kan brukes av alle profesjoner innen helse og omsorg, og er rettet mot de siste levedøgnene.

Liverpool Care Pathway er copyright-beskyttet. Alle steder i Norge der man bruker LCP må registreres hos Kompetansesenter i lindrande behandling Helse Vest (KLB), som har status som nasjonalt senter for LCP.

\section{Prosjektet i Vestfold}

Utviklingssenter for sykehjem og hjemmetjenester i Vestfold (USHT-V) har lindring som et satsingsområde, og vi har gjennomført flere kompetansehevende tiltak for helsepersonell innen fagområdet. I evalueringen av kompetanseprogrammet «Lindrende behandling til alvorlig syke og døende» i 2010 oppgir 84 prosent av deltakerne at de er opptatt av å kvalitetssikre pleieplanen i livets sluttfase, samt å bedre dokumentasjonen (4). Implementering av Liverpool Care Pathway kunne bidra til å imøtekomme dette. Prosjektet omfattet fylkets 14 kommuner, samt onkologisk-palliativ seksjon ved sykehuset i Vestfold HF. Målet var å ta i bruk LCP tiltaksplan ved alle forventete dødsfall.

Hensikten var å øke kompetansen hos per- sonalet. Vi ønsket å kvalitetssikre behandling, pleie og omsorg for døende og deres pårørende ved å sikre en mer helhetlig tilnærming og bedre dokumentasjonen av observasjoner og tiltak.

\section{Organisering}

Både institusjoner og hjemmebasert omsorg ønsket å implementere Liverpool Care Pathway. Ledelsen i hver kommune inngikk en skriftlig avtale med USHT om å delta i prosjektet. Innen hjemmebaserte tjenester ønsket man at prosjektet skulle forankres også hos kommuneoverlegen, for at fastlegene lettere kunne involveres. Ved sykehuset ble forankring av prosjektet gjort ved seksjonsoverlegen.

Prosjektet ble administrert av USHT-V, ved prosjektleder i 50 prosent stilling. Prosjektgruppe og styringsgruppe ble opprettet, med representanter for fagpersoner og administrativ ledelse i deltakerkommunene. I prosjektperioden har prosjektleder hatt jevnlig kontakt med nasjonal LCP-koordinator for veiledning og erfaringsutveksling.

\section{Omfang}

Vestfold har 36 sykehjem, hvorav 32 har deltatt i LCP-prosjektet. Ett sykehjem hadde implementert LCP før prosjektet, og ved de resterende sykehjemmene har man planlagt implementering. Ti av kommunene har også implementert Liverpool Care Pathway i hjemmebaserte tjenester. Det er planlagt å implementere LCP i de resterende hjemmetjenestene etter at prosjektperioden er avsluttet. I tre kommuner er LCP tatt i bruk ved flere bofellesskap for demente og døgnbemannete boliger. 

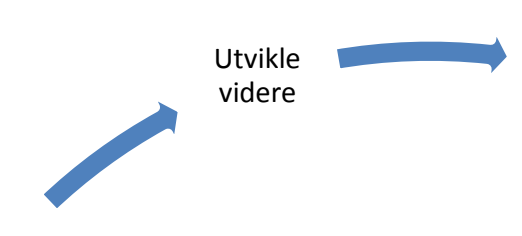

START

Etablere/

registrere

Videre-føre



Fast-holde



Audit Annen

evaluering

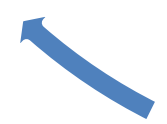

Følge opp



Opp-start

FIGUR: En 10-trinns modell, utviklet av Central Team i England.

På sykehuset i Vestfold er Liverpool Care Pathway implementert på onkologisk-palliativ seksjon. Planen er at LCP også skal tas i bruk på andre aktuelle sengeavdelinger på sykehuset.

\section{Implementeringen}

I samråd med USHT ble det i hver kommune eller på hvert brukersted etablert LCP-ansvarlige kontaktpersoner. Dette er ressurspersoner innen lindrende behandling, som i stor grad ble rekruttert via eksisterende interkommunalt fagnettverk i lindring. De LCP-ansvarlige ressurspersonene har hovedsakelig ivaretatt implementeringen på egne arbeidsplasser. Prosjektleder har ved etterspørsel bistått med undervisning og oppfølging for å sikre implementering på alle brukersteder, uavhengig av størrelse og ressurstilgang. For å kunne ivareta implementeringen i de fire største kommunene, har man med tilskuddsmidler frikjøpt en ressursperson i 20 prosent stilling.

Ved implementeringen anbefales det å bruke en ti-trinns modell i kontinuerlig prosess, utviklet av Central Team i England (2).

I Vestfold ble implementeringssirkelen fulgt fra start til audit i prosjektet. Hvert brukersted ble oppfordret til å ivareta de resterende trinnene, fastholde og videreføre bruken av LCP, med mål om optimal omsorg for døende og deres pårørende.

\section{Base Review}

Base Review er en gjennomgang av dokumentasjonen av omsorgen ved livets slutt før innføring av LCP, for å bli klar over kvaliteten på den eksisterende dokumentasjonen (3).

Fem store brukersteder i Vestfold utførte Base Review. Funnene var sammenfallende, uavhengig av pasientens diagnose og typen avdeling. Dokumentasjonen var svært mangelfull når det gjaldt behov og tilstand i livets sluttfase. Med unntak av pasientens fysiske smerte, var de færreste av fokusområdene i LCP-planen beskrevet. Journalene gir ikke nødvendigvis et riktig bilde av den behandling og pleie den enkelte pasient fikk. Sannsynligvis utføres det mange sykepleietiltak som aldri dokumenteres.

\section{Undervisning}

Ansatte i direkte pasientpleie fikk to timers obligatorisk fellesundervisning av implementeringsansvarlig på sin arbeidsplass. Powerpointpresentasjon om Liverpool Care Pathway, opplæring i bruk av tiltaksplanen og undervisning i lindrende pleie var på agendaen. Det ble vektlagt betydningen av å tilpasse behandling, omsorg og informasjon etter den enkelte pasients behov. Gjennomsnittlig har 80-85 prosent av ansatte på alle brukerstedene deltatt på undervisningen (5). Først etter gjennomført undervisning kunne de respektive stedene ta i bruk LCP i praksis.

\section{Informasjon til leger}

En forutsetning for å kunne ta i bruk LCP er at også legene har god kjennskap til tiltaksplanen, inkludert medikamentell behandling for å lindre symptom i livets sluttfase. Medikamentanbefalinger er utarbeidet av Kompetansesenter i lindrande behandling Helseregion Vest og Sunniva senter for lindrende behandling, Haraldsplass Diakonale Sykehus i Bergen (3). Anbefalingene er kun veiledende, og det er pasientens lege som må forordne type medikament og dose nøye tilpasset den enkelte pasients behov!

Det har vært en utfordring å nå alle legene med informasjon og undervisning. Fastlegene og de fleste kommuneoverlegene ble informert på e-post i tillegg til at informasjonsmapper er levert personlig på mange legekontor. LCPressurssykepleiere har informert i allmennlege- 
utvalg eller andre møtearenaer for kommunens fastleger, og det er gjennomført samarbeidsmøter med aktuelle fastleger for pasienter som ønsket å dø hjemme.

Sykehjemslegene ved noen sykehjem har deltatt på undervisningen for personalet. I tillegg har prosjektgruppen laget informasjonsmapper til sykehjemslegekontorene, som inneholder informasjon om LCP samt medikamentanbefalingene.

Sykehusets aktuelle leger deltok på intern fagdag for seksjonen, der blant annet LCP var tema. Forelesere var sykehjemslege ved USHT-V som har mye erfaring i bruk av tiltaksplanen, sammen med prosjektleder og seksjonens LCPansvarlige ressurssykepleier.

\section{Erfaringer}

Prosjektet er godt mottatt av både fagpersoner og administrativ ledelse i kommunene. Å ta i bruk et verktøy som LCP, bidrar til en felles standard på omsorgen, samt bedret dokumentasjon av tiltakene som utføres. Det er viktig å være bevisste på at LCP kun er et hjelpemiddel, og at omsorgen for døende ikke automatisk bedres kun ved bruk av LCP-planen.

\section{«LCP bidrar til en felles standard på omsorgen.»»}

Prosjektet oppfattes som relativt lite ressurskrevende, fordi innholdet er kjent og brukt i praksis allerede. Generelle tilbakemeldinger er at prosjektet har medført en mer bevisst måte å observere og imøtekomme behovene på, og at observasjoner og tiltak blir satt i system. Selv om tiltaksplanen er et skjema, vektlegges den enkelte pasient med individuelle behov, inkludert omsorg for pårørende.

Hva har LCP-implementeringen medført i Vestfold?

\section{Kompetanseheving}

Allerede i opplæringen ga mange uttrykk for at undervisningen i seg selv var et kompetanseløft. LCP bidrar til årvåkenhet hos helsepersonell når det gjelder observasjoner og vurderinger av hva som kan forårsake pasientens plager. Eksempelvis at mange døende utvikler urinretensjon, som kan være en viktig årsak til uro som ikke lar seg lindre medikamentelt (2). I tillegg gir LCP påminnelser om blant annet viktigheten av munnstell, leieforandringer og bruk av sirkulasjonsmadrass.
Bruken av LCP har også avdekket behov for øt kompetanse på konkrete områder, for eksempel subkutan administrasjon av medikamenter. Mange brukersteder har gjort tiltak for å heve kompetansen på flere områder.

Liverpool Care Pathway har bidratt til en mer helhetlig behandling og pleie. Økt kompetanse i observasjon og kunnskap om hvordan man best kan lindre ulike plager har ført til større bevissthet og engasjement hos personalet. Det har blitt mer rutine å gjennomføre samtaler om åndelige og eksistensielle behov hos pasienter og deres pårørende. Bruk av tolketjeneste for fremmedspråklige blir nå oftere vurdert.

\section{Bedre informasjon til pårørende}

LCP tiltaksplan etterspør essensielle temaer, for eksempel om pasient og pårørende er klar over diagnosen og at pasienten nå anses for å være døende. Dette fordrer kommunikasjon med pasient og pårørende. Man fokuserer mer enn tidligere på samtale med de pårørende om hva som kan forventes i den siste fasen av pasientens liv. Økt kunnskap hos personalet har ført til bedret informasjon og derved forutsigbarhet for pårørende. Det kan virke som LCP også har bevisstgjort personalet på samtaler med de pårørende om deres tanker, bekymringer og behov i situasjonen. Mange pårørende har gitt uttrykk for en positiv opplevelse av å få jevnlig og god oppfølging.

\section{Større åpenhet om døden}

LCP har medført at døende pasienter på avdelinger hvor palliasjon er mindre vektlagt enn det er på lindrende enheter, får mer kvalitetssikret symptomlindrende behandling, pleie og omsorg i livets siste fase. Dette gjelder også pasienter som dør av alderdomssvakhet uten spesielle diagnoser, og pasienter med kognitiv svikt.

Refleksjon og evaluering av pleien som utøves gjøres også i større grad enn før LCP-implementeringen. Det er større åpenhet rundt døden, både mellom helsepersonell og overfor pasienter og pårørende. LCP har bidratt til refleksjon over dilemmaer relatert til livets sluttfase, eksempelvis spørsmål om når medisinsk behandling skal avsluttes, hvem skal få informasjon, og når er det riktig eller ikke riktig å informere en pasient om at døden nærmer seg. LCP har ført til flere spørsmål på en positiv måte, større ydmykhet og færre selvsagte svar hos personalet. Implementeringen har også minnet oss på hvor viktig det er med refleksjon etter dødsfallet; hva gjorde vi bra, og hva kan vi forbedre.
Det å være et tverrfaglig team som sammen vurderer om pasienten er døende, gjør både sykepleiere og leger tryggere. Sykepleiere forteller at det å ivareta døende oppleves mindre tyngende og ensomt ved bruk av LCP. Med begrensete muligheter til å bygge klinisk kompetanse i pleie av døende, opplever også sykepleiere at LCP tilbyr et trygt rammeverk, ved at tiltaksplanen minner helsearbeiderne på viktige fokusområder. LCP beskrives som «godt for uerfarne».

\section{Bedret dokumentasjon}

Overgangen fra elektronisk til papirbasert pasientdokumentasjon har bydd på ulike reaksjoner. Innvendinger har vært at papirdokumentasjon og muntlige rapporter er tilbakeskritt, og at oversikten og helheten kan bli borte når dokumentasjonsform i et sykdomsforløp endres. Etter en tids bruk synes imidlertid de fleste at LCP-planen er en god måte å dokumentere på. Erfaringsutsagn er at nattsykepleiere som har ansvar for mer enn én avdeling på sykehjem, synes det er lettere å få oversikt over situasjonen til en døende pasient når all dokumentasjon finnes i ett papirdokument.

De fleste brukersteder melder tilbake at dokumentasjonen har blitt mer detaljert og systematisk. Dette bekreftes ved audit, som hittil er gjennomført ved to brukersteder, med Base Review som evalueringsgrunnlag. Fortsatt er det forbedringspotensial, og audit bør gjennomføres jevnlig på brukerstedene som utførte Base Review.

Et ankepunkt mot tiltaksplanen var at setningsformuleringene kan være gjenstand for misforståelser. Dette bekrefter at opplæring i bruk av planen er en forutsetning.

\section{I hjemmebaserte tjenester}

Å innføre Liverpool Care Pathway i hjemmetjenesten har vært spennende og utfordrende. Undervisningen til helsepersonell ble gjort som ved institusjonene, og personalet rapporterer om $ø \mathrm{kt}$ kompetanse. Informasjonen til fastlegene og den praktiske tilretteleggingen i hjemmetjenestens travle hverdag har krevd tålmodighet. Stort sett har legene vært positive til LCP, men kompetansen om og engasjementet for denne pasientgruppen har vært ulik. Forordning av anbefalte medikamenter til lindring i livets sluttfase, eksempelvis Midazolam og Robinul, har iblant vært en utfordring ettersom mange av fastlegene har lite erfaring med bruken av disse medikamentene fra sin praksis. Medikamentanbefalingene med doseringsforslag har 
vært en nyttig veileder. Noen leger har deltatt på fagdagene, der bruk av disse medikamentene har vært et tema. I tillegg har sykehjemsleger med erfaring i bruk av aktuelle medikamenter, ved etterspørsel veiledet fastleger som vil anvende medikamentene til pasienter som ønsker å dø hjemme.

Ikke alle kommunene har hatt forventete dødsfall hos hjemmeboende i prosjektperioden, og følgelig ikke fătt anvendt LCP-planen i praksis.

\section{Tidspunkt for å ta i bruk LCP}

Hvordan avklares situasjonen rundt en pasient som skal dø hjemme, og når skal man ta i bruk LCP-planen? Samarbeidet med fastlegene er en forutsetning for at LCP skal være et nyttig redskap, også for god dialog om svært viktige spørsmål når livet går mot slutten. Målet er at det etableres kontakt med fastlegen i god tid før LCP er aktuelt. Med utgangspunkt i pasientens situasjon kan samtalen dreies inn på tanker om tiden framover. Erfaringsmessig vet vi hvor nødvendig disse samtalene er både for pasienten, de pårørende og pleiepersonalet.

Vurderingene er alltid vanskelige og ekstra utfordrende i hjemmebaserte tjenester der fastlegen ikke er tilgjengelig til enhver tid. Vi har erfart at vi iblant har ventet for lenge med oppstart av LCP. Men det har også forekommet at LCP-planen har blitt tatt i bruk, men midlertidig avsluttet ved ny vurdering, fordi pasientens tilstand har bedret seg.

I hjemmetjeneste, så vel som på institusjoner av ulik størrelse inkludert lindrende enheter, har tiltaksplanen gjennomsnittlig vært i bruk ved 60-65 prosent av alle dødsfallene. Det rapporters om ulike årsaker til at planen ikke har vært anvendt ved alle dødsfall, men årsaken er hovedsakelig at pasientens tilstand har blitt raskt forverret, slik at dødsfallet kom brått. Fra alle stedene presiseres det at selv om tiltaksplanen ikke har vært brukt, har «LCPtankegangen» vært i personalets bevissthet vedrørende helhetlig lindring og ivaretakelse.

\section{Oppbevaring av LCP-planen}

Skal LCP-planen oppbevares i pasientens hjem eller på personalets kontor? Det ser ut til å være enighet om at den bør være på kontoret. Dette er av hensyn til taushetsplikten, med tanke på besøkende i hjemmet, og til rapporten mellom vaktskiftene, som baseres på dokumentasjonen i LCP-planen. I hjemmetjenester med store avstander beskrives rapport mellom vaktskiftene uten EPJ som et praktisk problem.

I tilknytning til LCP-prosjektet har man i mange kommuner laget et medikamentskrin som inneholder de fire anbefalte medikamentene. Målet er å sikre optimal symptomlindring i livets sluttfase hos hjemmeboende pasienter. Skrinet oppbevares på kommunal legevakt eller sykehjem, og medikamenter kan utleveres i henhold til gjeldende prosedyrer.

\section{Informasjon}

God informasjon og kommunikasjon er viktig for at pårørende skal forstå hva som skjer og klare å være hos den døende den siste tiden (2). I LCP tiltaksplan blir det jevnlig etterspurt om informasjon er gitt til pasient og pårørende. I tillegg til samtale kan brosjyren «Når livet går mot slutten», utgitt av Kirkens Bymisjon, benyttes for informasjon om hva som kan forventes når livet nærmer seg slutten.

LCP-prosjektet i Vestfold synliggjorde behovet for skriftlig informasjonsmateriale til etterlatte i forbindelse med dødsfall. Ny «Etterlattemappe» til bruk i kommunehelsetjenesten er utarbeidet, etter idé og kopitillatelse fra KLB Helseregion Vest. Første opplag av etterlattemappene er betalt av prosjektmidler og distribuert til alle brukerstedene.

\section{LCP på sykehuset}

Etter implementering av LCP på seksjon onkologi og palliasjon har tiltaksplanen vært anvendt ved cirka halvparten av alle dødsfall. Hos pasienter innlagt på en spesialavdeling kan symptombildet endres raskt, og det kan være vanskelig å vurdere om situasjonen skyldes reversible årsaker eller om pasienten er døende. Dette, i tillegg til at det kan oppstå akutte hendelser, gjør at LCP ikke har vært brukt ved alle dødsfallene.

Tilbakemeldingene på LCP er stort sett positive. Men det er uttrykt misnøye med at planen ikke er tilgjengelig i sykehusets elektroniske dokumentasjonssystem. Man arbeider med å få dette gjort. Personalet gir positiv tilbakemelding på at LCP fokuserer på det som er viktig for pasienten de siste timene og dagene. Fordi all ikke-essensiell behandling er seponert, har sykepleierne bedre anledning til å fokusere på lindrende tiltak. Kommunikasjon er essensielt i LCP tiltaksplan, og synliggjør den fortløpende dialogen som bør være mellom pasient, pårørende, lege og sykepleier. De eksistensielle behovene hos både pasient og pårørende blir bedre ivaretatt etter LCP-implementeringen.
Vår erfaring er at LCP er et verktøy som sikrer grunnleggende sykepleie og kvalitetssikrer at pasient og pårørende blir ivaretatt på best mulig måte. Avdelingens leger syns det er et godt verktøy når det er igangsatt, og behandlingsmålene er tydelige for alle involverte. Det er sykepleierne som foreløpig må være pådrivere for å ta i bruk LCP.

\section{Oppsummering}

Behovet for optimal symptomlindring i livets sluttfase er ikke et nytt tema, men innføring av LCP har gitt økt bevissthet på temaet. Personalet har blitt skolert i måter å lindre symptomer på, blant annet at de anbefalte behovsmedisinene må være tilgjengelig, og hvordan man administrerer disse.

Andre synlige konsekvenser av LCP-implementeringen er en større bevissthet på kommunikasjon og de viktige samtalene med pasient og pårørende. I tillegg bedre lindrende behandling på alle avdelinger, blant annet fordi helsepersonell blir påminnet viktige observasjonsområder. Personalet på langtidsavdelinger for somatikk og demens har nå mer fokus på optimal lindring i livets sluttfase for disse pasientgruppene.

Ved å ta i bruk LCP ved forventete dødsfall, blir god behandling, pleie og omsorg satt i system. Kvalitetssikret omsorg i livets sluttfase, uavhengig av pasientens diagnose og oppholdssted, synes å være nærmere nå enn før LCP-prosjektet. Dokumentasjonen har blitt bedret ved at måloppnåelse for behandling, pleie og omsorg jevnlig skal dokumenteres i tiltaksplanen.

Via samtaler og et uformelt spørreskjema har brukerstedene gitt tilbakemelding om at LCP fortsatt vil brukes uavhengig av prosjekt og oppfølging. Dette gir håp om at Liverpool Care Pathway har kommet for å bli i Vestfold. ıIII
REFERANSER

Saunders C. Pain and impending death. In: Melzack R, Wall P. Textbook of pain. London: Churchill Livingstone, 1994; 861. her: Husebø BS og Husebø S: De siste dager og timer. MEDLEX Norsk Helseinformasjon 2008,5. opplag, s.l. Ellershaw J, Wilkinson S. Care of the Dying, A pathway to excellence. Oxford: University Press, second edition 2011.

4. Bostrøm V. Disch PG. Lindrende omsorg ved livets slutt. En evaluering av et kompetanseutviklingsprogrami Vestfold. Senter for Omsorgsforskningrapportserie 2-2010

5. Paulsen SR. Rapport «Innføring av Liverpool Care Pathway i sykehjem og hjemmetjenester i Vestfold». Sandefjord kommune: Utviklingssenteret, 2013.

Fagartikler kan sendes til torhild.apall@sykepleien.no 